\title{
GRAFTING PERFORMANCE OF SOME WINE GRAPE (VITIS VINIFERA L.) CULTIVARS GRAFTED ON DIFFERENT AMERICAN GRAPEVINE ROOTSTOCKS
}

\author{
BEKAR, T. \\ Siirt University, Faculty of Agriculture, Horticulture Department, 56000 Siirt, Turkey \\ (e-mail: tubabekar@gmail.com,tubabekar@siirt.edu.tr; phone: 05422272137) \\ (Received $7^{\text {th }}$ Feb 2019; accepted $29^{\text {th }}$ Mar 2019)
}

\begin{abstract}
This study was conducted in the vine sapling production unit of "Kazova Vasfi Diren Agricultural Enterprise" located in central town of Tokat province in Turkey. The article attempted to graft five wine grape cultivars (Narince, Chardonnay, Merlot, Syrah, Öküzgözü) with five different American grapevine rootstocks (1103 Paulsen, 5BB, 41B, $110 \mathrm{R}, 140 \mathrm{Ru}$ ) in order to combat mainly Phylloxera, but also provide protection against nematodes, lime and salinity-like soil-borne problems. Sapling yields of different cultivar/rootstock combinations were investigated. While the greatest sapling yield was observed in Narince/1103 Paulsen combination (98.03\%), the lowest sapling yield was observed in Chardonnay/110R combination (43.64\%).
\end{abstract}

Keywords: vine rootstock, grapevine sapling, omega grafting, stratification room, sapling yield

\section{Introduction}

Phylloxera (Viteus vitifolii Fitch.) was first encountered in France in 1863, then spread to European and Turkish lands. This pest feeds on the roots of culture vines and causes the termination of several grape cultivars (Yayla, 2008). Therefore, viticulture through direct rooting of scions of the local grape cultivars will not be economical. Laliman observed that some American grapevine rootstocks were resistant to Phylloxera, thus resistance to Phylloxera was achieved through grafting culture cultivars on these rootstocks (Winkler et al., 1974). For an economic viticulture, it is more appropriate to establish vineyards with vine saplings grafted on American grapevine rootstocks. American vine rootstocks are not only resistant to Phylloxera, but also serve alternative solutions for the problems related to nematodes, lime, salinity and the other soil-borne problems (Çelik et al., 1998).

Success of grafting is generally understood as callus layer formation between the rootstock and scion tissues and full-bonding and cohesion of them into a single plant (Janick, 1986; Çelik, 2007). In vine sapling production, sapling quality and final take ratios are largely dependent on whether or not the vines from which grafting materials were taken are free of pests and diseases, nutritional status of grafting materials, pregrafting storage conditions of the rootstocks and scions, grafting method, attention paid to grafting, time of grafting, ambient conditions at stratification and following stages of grafted scions, mulching treatments, care and maintenance conditions after planting and the most important of all, cultivar/rootstock combinations (Kısmalı, 1978; Çelik and A ğaoğlu, 1982; Eriş et al., 1989; Kelen, 1994; Baydar and Ece, 2005).

Bhujbal (1993) used 1103P, 41B, SO4, Dogridge and Salt Creek rootstocks and Thompson Seedless cultivar and reported the best rooting and the greatest final take ratio for $1103 \mathrm{P}$ rootstock. 
Dardeniz and Şahin (2005) grafted Uslu and Yalova İncisi grape cultivars on 1103P, $5 \mathrm{BB}, 41 \mathrm{~B}$ and $140 \mathrm{Ru}$ rootstocks and reported the greatest final take ratios as $44.61 \%$ and $37.47 \%$ for Uslu cultivar respectively grafted on 41B and 5BB rootstocks.

A ğaoğlu and Çelik (1982) grafted Hamburg Misketi, Hafizali and Hasandede grape cultivars on Kober 5BB and 99R rootstocks and reported total final take ratios varied as between $20-60 \%$.

Kavak (2006) investigated the effects of Mycorrhiza and humic acid treatments on sapling final take ratios and reported the greatest grafting success $(70.00 \%)$ for Yalova Incisi/1103P combinations and the lowest success ratio (52.67\%) for Kalecik Karasi/1103 $\mathrm{P}$ and Kalecik Karas1/Fercal combinations.

Günen (2008) compared combinations of Cabernet Sauvignon and Syrah cultivars with five different rootstocks under open-field and greenhouse conditions and reported that ambient growth was significant. The greatest success was reported for Cabernet Sauvignon cultivar/1103 Paulsen combination as $90.08 \%$ in the first year and as $63.33 \%$ in the second year and for Syrah cultivar/1103 Paulsen combination as $91.67 \%$ in the first year and as $60.42 \%$ in the second year.

In this study, open-root sapling production was performed to assess the compatibility problems of commercially valuable wine grape cultivars of Narince, Chardonnay, Merlot, Syrah and Öküzgözü grafted on 1103 P, 5 BB, 41 B, $110 \mathrm{R}$ and $140 \mathrm{Ru}$ rootstocks commonly used in Turkey to propose solutions for Phylloxera, nematode, lime and salinity-like soil-born problems.

\section{Material and method}

This study was conducted in 2017 at the vine sapling production facility of Kazova Vasfi Diren Agricultural Enterprise in central town of Tokat province in Turkey (Figure 1). The $1103 \mathrm{P}, 5 \mathrm{BB}, 41 \mathrm{~B}, 110 \mathrm{R}$ and $140 \mathrm{Ru}$ American vine rootstocks and Narince, Chardonnay, Merlot, Syrah and Öküzgözü wine grape cultivars were used as the plant material of the study.

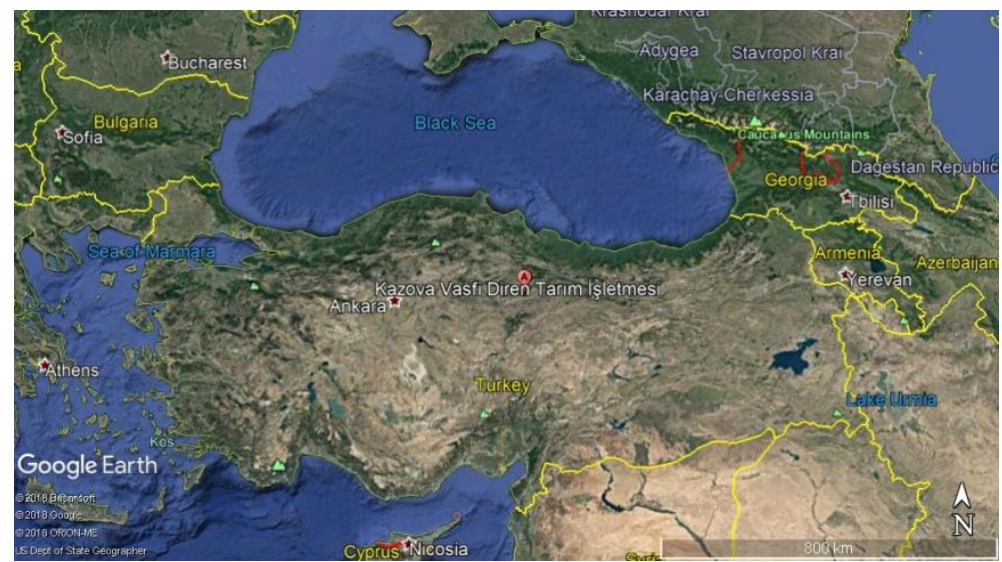

Figure 1. Study site

Shoots were taken from well-lignified mid-sections of annual branches, they were cut into single-bud scions and classified based on their thickness (7-8 $\mathrm{mm}, 9-10 \mathrm{~mm}$ and 11$12 \mathrm{~mm}$ thick) (Roux, 1988). Scions were treated with perlite moistened with water with 
$500 \mathrm{~g} / \mathrm{l}$ Fenhexamid active ingredient against grey mold disease (Botrytis cinerea). Treated scions were then placed into plastic bags and stored in a cold storage at $+4^{\circ} \mathrm{C}$ temperature for 2 months until the time of grafting (Figure 2).

Scions were cut into $30 \mathrm{~cm}$ long pieces as to have a single bud at the bottom and classified based on their thickness (7-8 mm, 9-10 mm and 11-12 mm thick). As can be seen in Figure 3, all buds were blunted except for the bottom one. Scions were then tied in bunches of 100 scions, placed into aseptic sacks and stored in a cold storage.

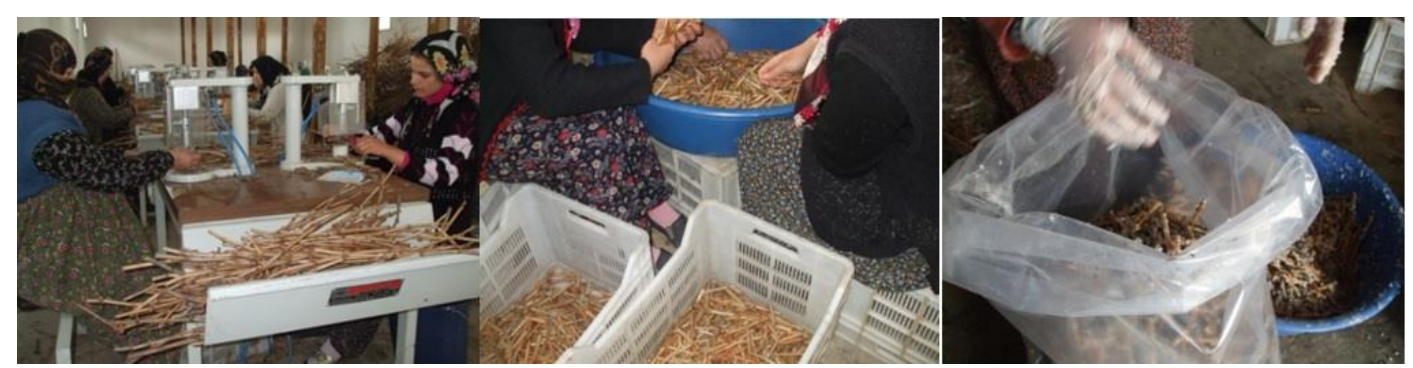

Figure 2. Processes applied to grafting scions

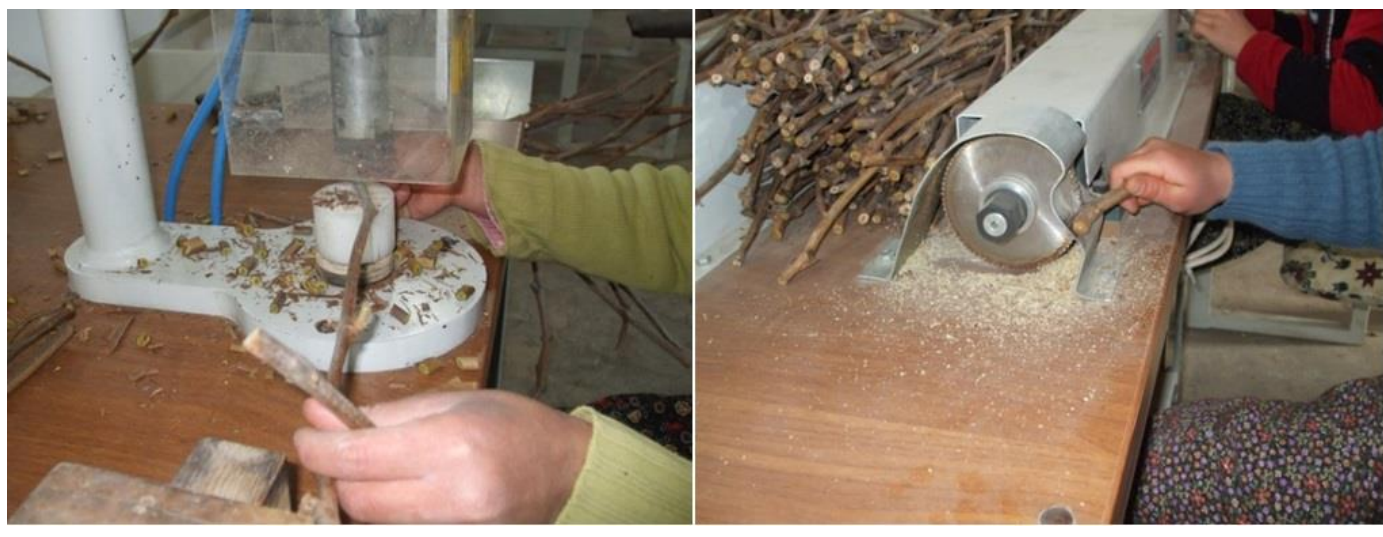

Figure 3. Processes applied to rootstocks

The scions (washed from the perlite over them) and rootstocks taken out of cold storage were kept outside (in a closed place) for three days. Rootstocks were kept in water-filled barrels and pools for two days (48 hours) and scions of the cultivars were kept in these places for one day (24 hours) (Figure 4). Just 6 hours before the end of this processes, $50 \%$ Benomyl was added only to holding water of scions to prevent the development of fungal diseases.

In this study, 37500 grafted scions were produced [5 wine cultivars (Narince, Chardonnay, Merlot, Syrah and Öküzgözü) X 5 American Vine Rootstocks (1103 Paulsen, 5 BB, 41 B, $110 \mathrm{R}$ and $140 \mathrm{Ru}$ ) X 3 replications X 500 grafted scions in each replicate] with omega bench grafting technique. Right after grafting, about $6 \mathrm{~cm}$ top section of grafted scions were coated with commercial paraffin prepared by using 1-5\% wax, Vaseline, resin, bitumen, tar, mineral oil as well as efficient rate of fungicide and auxin and melted at $82^{\circ} \mathrm{C}$. Following paraffin coating, grafted scions were taken into germination media and they were stacked into poplar shavings in Richter crates as recommended by Cangi et al. (2000) (Figure 5). 
Richter crates were then taken into stratification room for callusing. Stratification room conditions were arranged as $28-29^{\circ} \mathrm{C}$ temperature, $85-90 \%$ relative humidity and ventilation at every 6 hours (Çelik, 1982). The grafted scions left in Richter crates in stratification room for 21 days were taken out and placed in a closed facility for 2 days. Richter crates were opened, cleaned and second paraffin coating was applied to scions with full overall callusing. Grafted scions were placed into water pools for 12 days (a night) and they were removed from the water and rested for 2 days (Figure 6).

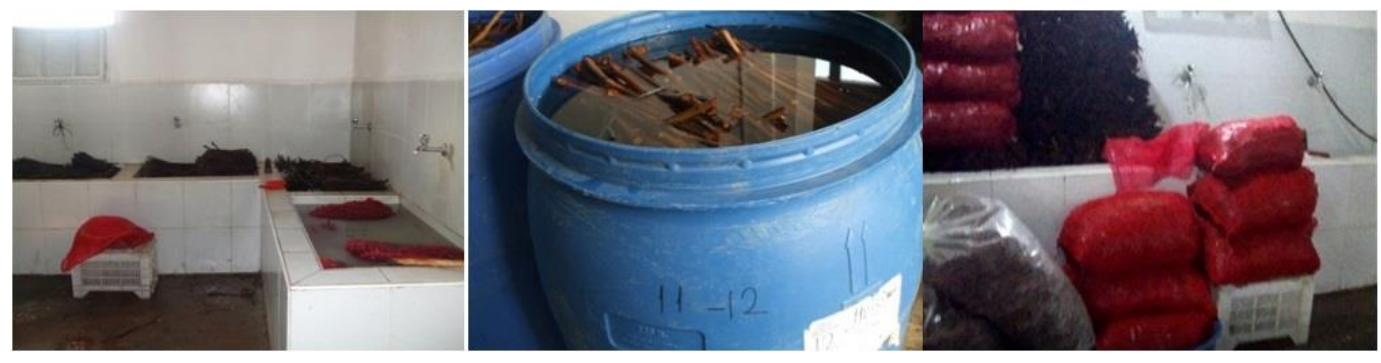

Figure 4. Pre-grafting processes applied to rootstocks and scions

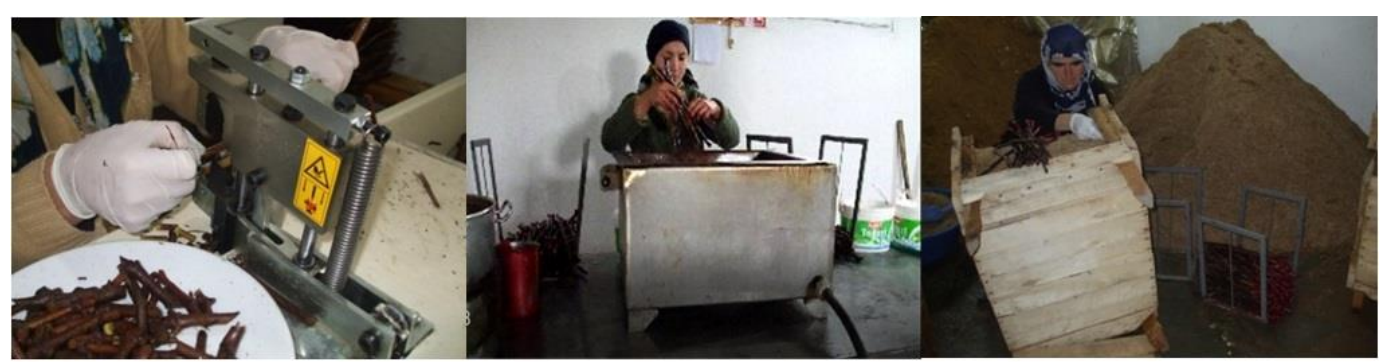

Figure 5. Omega grafting, paraffin coating and placement into Richter crates

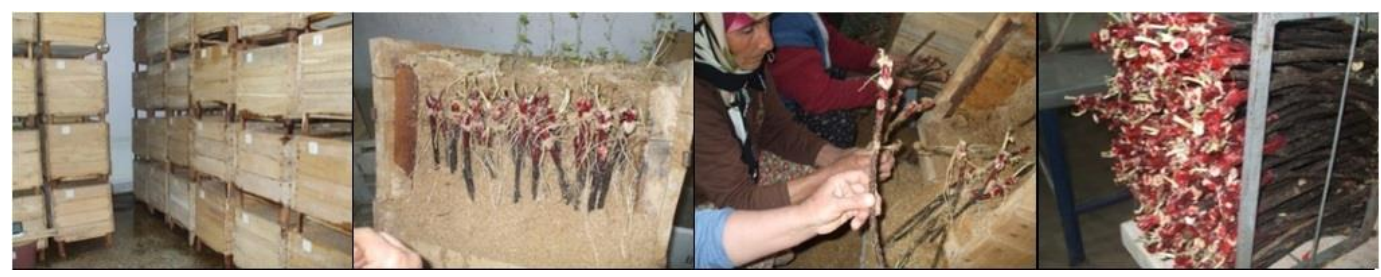

Figure 6. Processes applied after stratification room

Before to take the grafted scions to the field on $25^{\text {th }}$ of April, they were subjected to 2000 ppm IBA (indole-3 butyric acid) and planted onto previously mulch-covered seed beds at $20 \times 10 \mathrm{~cm}$ (row spacing x on-row plant spacing) spacing (Figure 7).

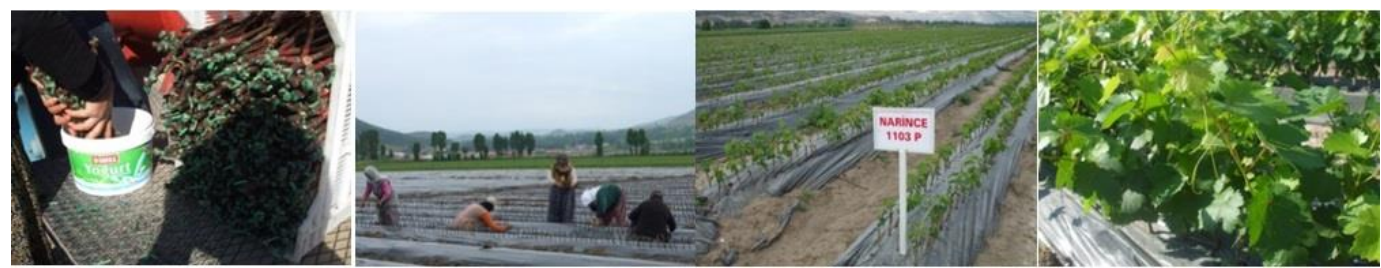

Figure 7. Plantation of grafted scions to the field 
Following the defoliation, saplings were removed from the field on $23^{\text {rd }}$ of November. Saplings offered for sale were counted and sapling yield (final take) (\%) for five wine grape cultivars and five American vine rootstock combinations was calculated as the ratio of number of saplings offered for sale to number of grafted scions.

$$
S Y=\left[\frac{N S O S}{N G S}\right] x 100
$$

where; SY= Sapling Yield $(\%)$, NSOS $=$ Number of Saplings Offered for Sale, NGS $=$ Number of Grafted Scions.

\section{Statistical analysis}

Experiments were conducted in randomized plots design with 3 replications. Following the analysis of variance, means were compared with Tukey's multiple range test at $1 \%$ significance level. JMP software was used in statistical analyses. Significant differences were indicated with the small letters by the data.

\section{Standard delusion $(S D)$}

Standard delusion calculations were performed to compare all experimental data in themselves.

\section{Results and discussion}

The results obtained for different cultivars are provided in Tables 1, 2, 3, 4 and 5. There were significant differences in number of saplings offered for sale and sapling yields of the cultivars $(\mathrm{p}<0.01)$.

In Narince cultivar, the greatest number of saplings offered for sale and sapling yield (491.33 and 98.27\%, respectively) were obtained from $1103 \mathrm{P}$ combination and the lowest values (265.33 and 53.07\%) were obtained from $110 \mathrm{R}$ combination (Table 1).

Table 1. Sapling yields for Narince cultivar with different rootstocks (Mean $\pm S D$ )

\begin{tabular}{c|c|c|c|c}
\hline CULTIVAR & ROOTSTOCKS & NGS & NSOS & SY (\%) \\
\hline \multirow{5}{*}{ NARINCE } & $\mathbf{1 1 0 3 ~ P}$ & 500 & $491.33 \pm 2.60 \mathrm{a}$ & $98.27 \pm 0.52 \mathrm{a}$ \\
& $\mathbf{5 ~ B B}$ & 500 & $424.00 \pm 2.08 \mathrm{c}$ & $84.80 \pm 0.42 \mathrm{c}$ \\
& $\mathbf{4 1 ~ B}$ & 500 & $457.00 \pm 3.21 \mathrm{~b}$ & $91.40 \pm 0.64 \mathrm{~b}$ \\
& $\mathbf{1 1 0 ~ R}$ & 500 & $265.33 \pm 1.45 \mathrm{e}$ & $53.07 \pm 0.29 \mathrm{e}$ \\
& $\mathbf{1 4 0 ~ R u}$ & 500 & $294.67 \pm 2.91 \mathrm{~d}$ & $58.93 \pm 0.58 \mathrm{~d}$ \\
\hline
\end{tabular}

The means indicated with different letters in the same column are significantly different according to Tukey's test at $\mathrm{p}<0.01$. NGS: Number of Grafted Scions, NSOS: Number of Saplings Offered for Sale, SY: Sapling Yield

In Chardonnay cultivar, the greatest number of saplings offered for sale and sapling yield (399.00 and $79.80 \%$, respectively) were obtained from $1103 \mathrm{P}$ combination and the lowest values (218.67 and $43.73 \%$ ) were obtained from $110 \mathrm{R}$ combination (Table 2). The differences between $5 \mathrm{BB}$ and $41 \mathrm{~B}$ rootstocks were not found to be significant. 
Table 2. Sapling yields for Chardonnay cultivar with different rootstocks (Mean $\pm S D$ )

\begin{tabular}{c|c|c|c|c}
\hline CULTIVAR & ROOTSTOCKS & NGS & NSOS & SY (\%) \\
\hline & $\mathbf{1 1 0 3 ~ P}$ & 500 & $399.00 \pm 5.20 \mathrm{a}$ & $79.80 \pm 1.04 \mathrm{a}$ \\
& $\mathbf{5 ~ B B}$ & 500 & $375.33 \pm 1.45 \mathrm{~b}$ & $75.07 \pm 0.29 \mathrm{~b}$ \\
CHARDONNAY & $\mathbf{4 1 ~ B}$ & 500 & $373.67 \pm 2.60 \mathrm{~b}$ & $74.73 \pm 0.52 \mathrm{~b}$ \\
& $\mathbf{1 1 0 ~ R}$ & 500 & $218.67 \pm 1.20 \mathrm{~d}$ & $43.73 \pm 0.24 \mathrm{~d}$ \\
& $\mathbf{1 4 0 ~ R u}$ & 500 & $277.33 \pm 1.20 \mathrm{c}$ & $55.47 \pm 0.24 \mathrm{c}$ \\
\hline
\end{tabular}

The means indicated with different letters in the same column are significantly different according to Tukey's test at $\mathrm{p}<0.01$. NGS: Number of Grafted Scions, NSOS: Number of Saplings Offered for Sale, SY: Sapling Yield

In Merlot cultivar, the greatest number of saplings offered for sale and sapling yield (413.00 and $82.60 \%$, respectively) were obtained from $1103 \mathrm{P}$ combination and the lowest values (269.00 and 53.80\%) were obtained from $110 \mathrm{R}$ combination. The differences between $1103 \mathrm{P}$ and $5 \mathrm{BB}$ rootstocks were not found to be significant (Table 3).

Table 3. Sapling yields for Merlot cultivar with different rootstocks (Mean $\pm S D$ )

\begin{tabular}{c|c|c|c|c}
\hline CULTIVAR & ROOTSTOCKS & NGS & NSOS & SY (\%) \\
\hline \multirow{4}{*}{ MERLOT } & $\mathbf{1 1 0 3 ~ P}$ & 500 & $413.00 \pm 2.08 \mathrm{a}$ & $82.60 \pm 0.42 \mathrm{a}$ \\
& $\mathbf{5 ~ B B}$ & 500 & $407.67 \pm 2.03 \mathrm{a}$ & $81.53 \pm 0.41 \mathrm{a}$ \\
& $\mathbf{4 1 ~ B}$ & 500 & $373.67 \pm 5.21 \mathrm{~b}$ & $74.73 \pm 1.04 \mathrm{~b}$ \\
& $\mathbf{1 1 0 ~ R}$ & 500 & $269.00 \pm 2.08 \mathrm{~d}$ & $53.80 \pm 0.42 \mathrm{~d}$ \\
& $\mathbf{1 4 0 ~ R u}$ & 500 & $297.33 \pm 4.33 \mathrm{c}$ & $59.47 \pm 0.87 \mathrm{c}$ \\
\hline
\end{tabular}

The means indicated with different letters in the same column are significantly different according to Tukey's test at $\mathrm{p}<0.01$. NGS: Number of Grafted Scions, NSOS: Number of Saplings Offered for Sale, SY: Sapling Yield

In Syrah cultivar, the greatest number of saplings offered for sale and sapling yield (391.33 and $78.27 \%$, respectively) were obtained from $1103 \mathrm{P}$ combination and the lowest values (254.33 and 50.87\%) were obtained from $110 \mathrm{R}$ combination (Table 4).

Table 4. Sapling yields for Syrah cultivar with different rootstocks (Mean $\pm S D$ )

\begin{tabular}{c|c|c|c|c}
\hline CULTIVAR & ROOTSTOCKS & NGS & NSOS & SY (\%) \\
\hline \multirow{5}{*}{ SYRAH } & $\mathbf{1 1 0 3 ~ P}$ & 500 & $391.33 \pm 2.33 \mathrm{a}$ & $78.27 \pm 0.47 \mathrm{a}$ \\
& $\mathbf{5 ~ B B}$ & 500 & $364.00 \pm 2.52 \mathrm{~b}$ & $72.80 \pm 0.50 \mathrm{~b}$ \\
& $\mathbf{4 1 ~ B}$ & 500 & $379.00 \pm 1.53 \mathrm{ab}$ & $75.80 \pm 0.31 \mathrm{ab}$ \\
& $\mathbf{1 1 0} \mathbf{R}$ & 500 & $254.33 \pm 3.76 \mathrm{~d}$ & $50.87 \pm 0.75 \mathrm{~d}$ \\
& $\mathbf{1 4 0 ~ R u}$ & 500 & $310.33 \pm 1.20 \mathrm{c}$ & $62.07 \pm 0.24 \mathrm{c}$ \\
\hline
\end{tabular}

The means indicated with different letters in the same column are significantly different according to Tukey's test at $\mathrm{p}<0.01$. NGS: Number of Grafted Scions, NSOS: Number of Saplings Offered for Sale, SY: Sapling Yield 
In Öküzgözü cultivar, the greatest number of saplings offered for sale and sapling yield (376.67 and $75.33 \%$, respectively) were obtained from $1103 \mathrm{P}$ combination and the lowest values ( 248.67 and $49.73 \%$ ) were obtained from $110 \mathrm{R}$ combination (Table 5).

In a previous study comparing different cultivar/rootstock combinations under Isparta conditions, grafted vine saplings were produced through omega bench grafting and the greatest final take values were respectively reported for Razak1/SO4 combination (97.22\%), Alphonse Lavallèe/SO4 combination (98.33\%) and Italia/1103 Paulsen combination (98.04\%) (Baydar and Ece, 2005). In present study, the greatest final take values (yield) of all cultivars were reported for 1103 Paulsen combination.

Table 5. Sapling yields for Öküzgözü cultivar with different rootstocks (Mean $\pm S D$ )

\begin{tabular}{c|c|c|c|c}
\hline CULTIVAR & ROOTSTOCKS & NGS & NSOS & SY (\%) \\
\hline & $\mathbf{1 1 0 3 ~ P}$ & 500 & $376.67 \pm 0.33 \mathrm{a}$ & $75.33 \pm 0.07 \mathrm{a}$ \\
ÖKÜZGÖZÜ & $\mathbf{5 ~ B B}$ & 500 & $355.67 \pm 2.60 \mathrm{~b}$ & $71.13 \pm 0.52 \mathrm{~b}$ \\
& $\mathbf{4 1 ~ B}$ & 500 & $367.33 \pm 2.33 \mathrm{ab}$ & $73.47 \pm 0.47 \mathrm{ab}$ \\
& $\mathbf{1 1 0 ~ R}$ & 500 & $248.67 \pm 1.45 \mathrm{~d}$ & $49.73 \pm 0.29 \mathrm{~d}$ \\
& $\mathbf{1 4 0 ~ R u}$ & 500 & $322.00 \pm 2.31 \mathrm{c}$ & $64.40 \pm 0.46 \mathrm{c}$ \\
\hline
\end{tabular}

The means indicated with different letters in the same column are significantly different according to Tukey's test at $\mathrm{p}<0.01$. NGS: Number of Grafted Scions, NSOS: Number of Saplings Offered for Sale, SY: Sapling Yield

The greatest number of saplings offered for sale (491.33\%) was obtained from Narince/1103 P interaction and the lowest value (218.67\%) was obtained from Chardonnay/110 R interaction. The greatest sapling yield $(98.27 \%)$ was obtained from Narince/1103 P interaction and the lowest value (43.73\%) was obtained from Chardonnay/110 R interaction. While the greatest number of saplings offered for sale and sapling yields were observed in scions grafted on $1103 \mathrm{P}$ rootstock and the lowest values were observed in scions grafted on $110 \mathrm{R}$ rootstock. The differences in relevant values of Chardonnay/5 BB, Chardonnay/41 B, Merlot/41 B, Öküzgözü/1103 P, Chardonnay/140 $\mathrm{Ru}$ and Merlot/110 R interactions were not found to be significant (Table 6).

İşçi and Altındişli (2006) cleft-grafted different grape cultivars on rooted American vine rootstocks in place and reported final take ratios in $41 \mathrm{~B}$ and $110 \mathrm{R}$ rootstocks respectively as 83 and $100 \%$ for Yuvarlak Çekirdeksiz cultivar, as 77 and $83 \%$ for Red Globe cultivar, as 84 and $80 \%$ for Buca Razakısı cultivar, as 100 and $81 \%$ for Trakya İlkereni cultivar and as 96 and $87 \%$ for Alphonse Lavallèe cultivar. Similar different values were also observed in this study for different cultivars.

Alço et al. (2015) investigated the grafting room performance of different cultivar/rootstock combinations and reported grafting room performance of Cardinal, Merlot and Cabernet Sauvignon grape cultivars grafted on $110 \mathrm{R}$ rootstock respectively as $96.50,98.75$ and $98.75 \%$ in 2012 and as $97.75,96.25$ and $86.25 \%$ in 2013 . Researchers reported the grafting room performance of the same grape cultivars grafted on $5 \mathrm{BB}$ rootstock respectively as $99.50,99.75$ and $99.50 \%$ in 2012 and as $74.25,70.50$ and $86.75 \%$ in 2013. Present values obtained for Merlot/110 R and 5 BB combinations were lower than those values.

Günen and Altındişli (2017) compared combinations of Cabernet Sauvignon cultivar with three different rootstocks in open field and undercover conditions. Researchers indicated that growth ambient did not have significant effects on grafting success ratios 
and reported the greatest grafting success for 1103 Paulsen rootstock as $90.08 \%$ in the first year and as $63.33 \%$ in the second year, the lowest grafting success for $110 \mathrm{R}$ rootstock in the first year $(53.18 \%)$ and for $99 \mathrm{R}$ rootstock in the second year $(23.34 \%)$. Present findings were parallel to those results obtained for $1103 \mathrm{R}$ rootstock.

Table 6. Sapling yields of cultivar/rootstock interactions (Mean $\pm S D$ )

\begin{tabular}{|c|c|c|c|c|}
\hline CULTIVARS & ROOTSTOCKS & NGS & NSOS & SY (\%) \\
\hline \multirow{5}{*}{ Narince } & $1103 P$ & 500 & $491.33 \pm 2.60 \mathrm{a}$ & $98.27 \pm 0.52 \mathrm{a}$ \\
\hline & 5 BB & 500 & $424.00 \pm 2.08 \mathrm{c}$ & $84.80 \pm 0.42 \mathrm{c}$ \\
\hline & $41 \mathrm{~B}$ & 500 & $457.00 \pm 3.21 \mathrm{~b}$ & $91.40 \pm 0.64 \mathrm{~b}$ \\
\hline & $110 \mathrm{R}$ & 500 & $265.33 \pm 1.45 \mathrm{mn}$ & $53.07 \pm 0.29 \mathrm{mn}$ \\
\hline & $140 \mathrm{Ru}$ & 500 & $294.67 \pm 2.911$ & $58.93 \pm 0.581$ \\
\hline \multirow{5}{*}{ Chardonnay } & $1103 P$ & 500 & $399.00 \pm 5.20 \mathrm{de}$ & $79.80 \pm 1.04 \mathrm{de}$ \\
\hline & $5 \mathrm{BB}$ & 500 & $375.33 \pm 1.45 \mathrm{gh}$ & $75.07 \pm 0.29 \mathrm{gh}$ \\
\hline & $41 \mathrm{~B}$ & 500 & $373.67 \pm 2.60 \mathrm{gh}$ & $74.73 \pm 0.52 \mathrm{gh}$ \\
\hline & $110 R$ & 500 & $218.67 \pm 1.20 \mathrm{p}$ & $43.73 \pm 0.24 \mathrm{p}$ \\
\hline & $140 \mathrm{Ru}$ & 500 & $277.33 \pm 1.20 \mathrm{~m}$ & $55.47 \pm 0.24 \mathrm{~m}$ \\
\hline \multirow{5}{*}{ Merlot } & $1103 P$ & 500 & $413.00 \pm 2.08 \mathrm{~cd}$ & $82.60 \pm 0.42 \mathrm{~cd}$ \\
\hline & 5 BB & 500 & $407.67 \pm 2.03 \mathrm{~d}$ & $81.53 \pm 0.41 \mathrm{~d}$ \\
\hline & $41 \mathrm{~B}$ & 500 & $373.67 \pm 5.21 \mathrm{gh}$ & $74.73 \pm 1.04 \mathrm{gh}$ \\
\hline & $110 R$ & 500 & $269.00 \pm 2.08 \mathrm{~m}$ & $53.80 \pm 0.42 \mathrm{~m}$ \\
\hline & $140 \mathrm{Ru}$ & 500 & $297.33 \pm 4.33 \mathrm{kl}$ & $59.47 \pm 0.87 \mathrm{kl}$ \\
\hline \multirow{5}{*}{ Syrah } & $1103 P$ & 500 & $391.33 \pm 2.33 \mathrm{ef}$ & $78.27 \pm 0.47$ ef \\
\hline & $5 \mathrm{BB}$ & 500 & $364.00 \pm 2.52 \mathrm{~h} 1$ & $72.80 \pm 0.50 \mathrm{~h}_{1}$ \\
\hline & $41 \mathrm{~B}$ & 500 & $379.00 \pm 1.53 \mathrm{fg}$ & $75.80 \pm 0.31 \mathrm{fg}$ \\
\hline & $110 R$ & 500 & $254.33 \pm 3.76$ no & $50.87 \pm 0.75$ no \\
\hline & $140 \mathrm{Ru}$ & 500 & $310.33 \pm 1.20 \mathrm{jk}$ & $62.07 \pm 0.24 \mathrm{jk}$ \\
\hline \multirow{5}{*}{ Öküzgözü } & $1103 P$ & 500 & $376.67 \pm 0.33 \mathrm{gh}$ & $75.33 \pm 0.07 \mathrm{gh}$ \\
\hline & $5 \mathrm{BB}$ & 500 & $355.67 \pm 2.601$ & $71.13 \pm 0.521$ \\
\hline & $41 \mathrm{~B}$ & 500 & $367.33 \pm 2.33$ gh1 & $73.47 \pm 0.47 \mathrm{gh} 1$ \\
\hline & $110 R$ & 500 & $248.67 \pm 1.45 \mathrm{o}$ & $49.73 \pm 0.29$ o \\
\hline & $140 \mathrm{Ru}$ & 500 & $322.00 \pm 2.31 \mathrm{j}$ & $64.40 \pm 0.46 \mathrm{j}$ \\
\hline
\end{tabular}

The means indicated with different letters in the same column are significantly different according to Tukey's test at $\mathrm{p}<0.01$. NGS: Number of Grafted Scions, NSOS: Number of Saplings Offered for Sale, SY: Sapling Yield

Çelik and Gider (1991) grafted Alphonse Lavallèe and Cardinal grape cultivars on 1103 Paulsen, 5 BB and S04 rooted rootstocks and indicated that grafting success varied with the cultivar/rootstock combinations and reported the greatest grafting success $(98.08 \%)$ for Cardinal/1103P combination. Present findings were similar with those findings.

Eroğlu (2014) grafted Alphonse Lavallèe and Red Globe grape cultivars on $110 \mathrm{R}$ and 1103 P rootstocks and investigated the effects of different biological preparates on sapling performance. Researcher reported grafting success in $110 \mathrm{R}$ and $1103 \mathrm{P}$ rootstocks respectively as 97.00 and $99.00 \%$ for Alphonse Lavallèe cultivar and as 97.60 and $97.90 \%$ 
for Red Globe cultivar. While present findings were lower than those findings on $110 \mathrm{R}$ and were parallel to findings on $1103 \mathrm{P}$ rootstock.

Çoban and Kara (2003) investigated sapling quality of combinations of four different grape cultivars and three different American vine root stocks and reported sapling performance of Lival, Ribol, Danam and Datal cultivars respectively as 51.0, 60.0, 61.0 and $70.0 \%$ in 5 BB rootstock, as 45.0, 65.0, 60.0 and 65.0\% in $99 \mathrm{R}$ rootstock and as 48.6, $50.0,60.0$ and $60.0 \%$ in $110 \mathrm{R}$ rootstock.

Çakır and Yücel (2016) investigated grafting performance of Narince and Kalecik Karas1 grape cultures on 1103 Paulsen rootstock and reported callus formation ratios as $77 \%$ in Narince and as $60 \%$ in Kalecik Karas 1 grape cultivar.

Yağc1 and Gökkaynak (2016) investigated sapling performance of Sultani Seedless grape cultivar on different rootstocks (110 R, 140 Ruggeri, 1613 C, 5 BB and Ramsey) and reported total sapling performance respectively as 51.5, 40.4, 50.3, 57.3 and 50.2\%. While present findings were lower than those findings on $5 \mathrm{BB}$ rootstock, they were parallel to findings on $110 \mathrm{R}$ rootstock.

\section{Conclusion}

With the intrusion of Phylloxera pest into vineyards, local viticulture practices have become impossible in Turkey. Therefore, growers had to establish their vineyards with American vine rootstocks resistant to Phylloxera, well-adapted to ecological conditions and with a good affinity to grape cultivars to be grown. This study was conducted through omega bench grafting of five different wine grape cultivars (Narince, Chardonnay, Merlot, Syrah and Öküzgözü) on five different American vine rootstocks (1103 P, 5 BB, $41 \mathrm{~B}, 110 \mathrm{R}$ and $140 \mathrm{Ru}$ ) compatible with different soil characteristics of Turkish vineyards. While the greatest sapling yield (98.03\%) was observed in Narince/1103 Paulsen combination, the lowest yield (43.64\%) was observed in Chardonnay/110R combination. Present findings provide significant background information against potential incompatibilities in grafted vine saplings. Before to decide on any combinations, compatibility and affinity of the available rootstocks to the cultivar, adaptation of the rootstocks to local ecological conditions, effects of the rootstocks on yield, quality, growth, development and nourishment of the cultivar all should be well put forth. Such attributes of the rootstocks should be taken into consideration while recommending rootstocks to growers for the cultivars they wish to grow. Such appropriate recommendations will have great contributions to success and yield in viticulture activities of the growers.

\section{REFERENCES}

[1] Ağaoğlu, Y. S., Çelik, H. (1982): Effect of grafting machines on success of grafted vine production. - U.Ü. Zir. Fak. Dergisi. 1: 25-32.

[2] Alço, T., Dardeniz, A., Sağlam, M., Özer, C., Açıkbaş, B. (2015): The effects of different cultivar/rootstock combinations on grafting room efficiency and callus formation in grafted vines (Aşılı asma fidanı üretiminde farklı çeşit/anaç kombinasyonlarının aşı odası randımanı ile kallus gelişim düzeyi üzerine etkileri). - Selçuk Üniversitesi, Selçuk Tarım ve Gıda Bilimleri Dergisi-A 27 (Türkiye 8. Bağcılık ve Teknolojileri Sempozyumu Özel Say1s1): s. 8-16. 
[3] Baydar, N. G., Ece, M. (2005): Comparation of different scion/rootstock combinations in the production of grafted grapevines in Isparta condition (Isparta koşullarında aşılı asma fidanı üretiminde farklı çeşit/anaç kombinasyonlarının karşılaştııılması). - Süleyman Demirel Üniversitesi, Fen Bilimleri Enstitüsü Dergisi, 9-3.

[4] Bhujbal, B. G. (1993): Performance of five grape rootstocks for rooting and grafting. Maharashtra Journal of Horticulture 7(1): 7-9.

[5] Cangi, R., Balta, F., Doğan, A. (2000): Anatomical and histological investigations on the effects of stratification substrates on final take and quality of grafted vines (Aş1lı asma fidanı üretiminde kullanılan katlama ortamlarının fidan randıman ve kalitesi üzerine etkilerinin anatomik ve histolojik olarak incelenmesi). - Türk JagricFor. 24: 393-398.

[6] Çakır, A., Yücel, B. (2016): Determination of Narince and Kalecik Karasi grape varieties with paulsen 1103 grapevine rootstocks grafting performance (Narince ve Kalecik Karas1 üzüm çeşitlerinin 1103 Paulsen amerikan asma anacı ile aşı performanslarının belirlenmesi). - Türk Tarım ve Doğa Bilimleri Dergisi 3(4): 311-317.

[7] Çelik, H. (1982): The effects of different stratification room and NAA applications in the production of grafted-rooted grapevine sapling in greenhouse conditions for Kalecik Karası/41 B grafting combination (Kalecik karas1/41 B aşı kombinasyonu için ser koşullarında yapılan aş111-köklü fidan üretiminde değişik köklenme ortamları ve NAA uygulamalarının etkileri). - Doçentlik tezi (basılmamış), Ankara, s. 73.

[8] Çelik, S., Gider, S. (1991): Grafting the rooted-rootstocks, planted to establish a vineyard, within same year (Bağ kurmak amacıyla dikilen köklü anaçların aynı yıl içinde aşılanması). - T.C. Tarım ve Köyişleri Bakanlığı Türkiye 1. Fidancılık Sempozyumu, Ankara, 113-121.

[9] Çelik, H., Ağaoğlu, Y. S., Fidan, Y., Marasalı, B., Söylemezoğlu, G. (1998): General Viticulture (Genel Bağcılık). - Sun Fidan A. Ş. Mesleki Kitaplar Serisi: 1, Ankara, s. 253.

[10] Celik, S. (2007): Viticulture Ampelology [Bağc1lık (Ampeloloji)]. - Namık Kemal Üniversitesi, Ziraat Fakültesi, Bahçe Bitkileri Bölümü. Cilt I. Genişletilmiş 2. Baskı. 428 s. Tekirdağ.

[11] Coban, H., Kara, S. (2003): Investigations on the effect of some grape (Vitis vinifera L.) variet1es grafted on different rootstocks on the quality of grapevine saplings (Bazı üzüm (Vitis vinifera L.) çeşitlerinin asma anaçları ile aşı tutma durumu ve fidan kalitesine etkileri üzerine araştırmalar). - Journal of Aegean Agricultural Research Institute 13(1): 176-187.

[12] Dardeniz, A., Şahin, A. O. (2005): The effects of the combinations of different varieties and rootstocks on the vegetative growth and nursery plant ratio for the production of grafted vine rootstocks (Aşı1ı asma fidanı üretiminde farklı çeşit ve anaç kombinasyonlarının vejetatif gelişme ve fidan randımanı üzerine etkileri). - Bahçe Dergisi. 34(2): 1-9.

[13] Eriş, A., Soylu, A., Türkben, C. (1989): The effects of some applications on callus formation and rooting at the grafted site in the production of grafted-rooted grapevine sapling (Aşı1ı köklü asma fidanı üretiminde bazı uygulamaların aşı yerinde kallus oluşumu ve köklenme üzerine etkileri). - Bahçe 18(1-2): 29-34.

[14] Eroğlu, D. (2014): The effects of different biological preparation applicatıons on grafted saplıng propagatıon in pots of some grape cultıvars (Bazı üzüm çeşitlerinin aşılı tüplü fidan üretimlerinde farklı biyolojik preparat uygulamalarının etkileri). - Adnan Menderes Üniversitesi, Fen Bilimleri Enstitüsü (Yüksek Lisans Tezi), 81 s., Aydın.

[15] Günen, E. (2008): Investigations on the effects of different rootstock-scion relations and propagation types on yield and quality of tubed vine grafts (Bazı şaraplık üzüm çeşitlerinin aş11 köklü asma fidanlarının üretiminde anaç kalem ilişkileri ve üretim şekillerinin fidan randımanı ile kalitesine etkileri üzerinde araştırmalar). - Ege Üniversitesi, Fen Bilimleri Enstitüsü (Doktora Tezi), s. 217. Bornova, İzmir.

[16] Günen, E., Altındişli, A. (2017): An assesment of tube sapling performance of graft combinations of Cabernet Sauvignon grape variety with some american rootstocks under greenhouse and open field conditions (Cabernet Sauvignon üzüm çeşidinin bazı amerikan asma anaçları ile aşı kombinasyonlarının örtü altı ve açıkta yetiştiricilik koşullarında tüplü fidan performanslarının değerlendirilmesi). - Ege Üniv. Ziraat Fak. Derg. 54(1): 91-99. 
[17] İşçi, B., Altındişli, A. (2006): A research on take ratio of some grapes varieties of 41B and $110 \mathrm{R}$ american rootstock (Bazı üzüm çeşitlerinin $41 \mathrm{~B}$ ve $110 \mathrm{R}$ amerikan asma anaçları ile aşı tutma yüzdesi üzerine araştırmalar). - Ege Üniv. Ziraat Fak. Derg., 43(2): 13-25.

[18] Janick, J. (1986): Horticultural Science. - 4th. ed., W. H. Freeman and Company, New York, 39: 346. 746.

[19] Kavak, O. (2006): The effects of mychorriza and humic acid applications on quality of grafted and potted plant propagation in grapes (Aşılı köklü ve tüplü asma fidanı üretiminde fidan kalite özelliklerine mikoriza ve humik asit uygulamalarının etkileri). - Selçuk Üniversitesi, Fen Bilimleri Enstitüsü (Yüksek Lisans Tezi), KONYA. s. 52.

[20] Kelen, M. (1994): Investigations on the effects of some applications on the yield and quality of sapling in the production of grafted-rooted grapevine sapling, on the anatomical and histological investigation of grafted fusion (Bazı uygulamaların aş111-köklü asma fidanı üretiminde fidan randımanı ve kalitesi üzerine etkileri ile aşı kaynaşmasının anatomik ve histolojik olarak incelenmesi üzerine araştırmalar). - Y.Y.Ü. Fen Bil. Ens. (Doktora Tezi), VAN, $131 \mathrm{~s}$.

[21] K1smal1, İ. (1978): Investigations on the production of grafted-rooted grapevine sapling made with Yuvarlak Çakirdeksiz grape varieties and different American grapevine rootstocks (Yuvarlak Çekirdeksiz üzüm çeşidi ve farklı Amerikan asma anaçları ile yapılan aşı1ı köklü asma fidanı üretimi üzerinde araştırmalar). - Basılmamış Doçentlik Tezi. $102 \mathrm{~s}$.

[22] Roux Le, D. J. (1988): The collection and storage of vineyard grafting material. - VORI leaflet, 209. Stellenbosch, South Africa, 2 p.

[23] Winkler, A. J., Cook, J. A., Kliewer, W. M., Lider, L. A. (1974): General Viticulture. University of California Press., Berkeley and Los Angeles, 633 p.

[24] Yağc1, A., Gökkaynak, A. G. (2016): The effect of rootstock and shading ratio on seedling performance and quality of Sultani Çekirdeksiz grape cultivar (Sultani Çekirdeksiz üzüm çeşidinin fidan randımanı ve kalitesi üzerine anaç ve gölgeleme oranının etkisi). - Ege Üniv. Ziraat Fak. Derg. 53(1): 109-116.

[25] Yayla, F. (2008): Investigation of wine characteristics of grape varieties in local collection vineyards (project intermediate report) [Milli koleksiyon bağındaki üzüm çeşitlerinin şaraplık özelliklerinin araştırılması (proje ara sonuç raporu)]. - s. 4, Bağcılık Araştırma Enstitüsü Müdürlüğü, Tekirdăg. 